\title{
Enhanced levels of asymmetric dimethylarginine in a serum of middle age patients with myelodysplastic syndrome
}

\author{
Jana Štikarová, Jiř́ Suttnar*, Kristýna Pimková, Leona Chrastinová-Mášová, Jaroslav Čermák and Jan E Dyr
}

\begin{abstract}
Myelodysplastic syndromes (MDS) are hematological malignancies of unclear etiology where oxidative stress may contribute to the pathogenesis. Methylarginines, naturally occurring inhibitors of NO synthase, can increase superoxide generation from uncoupled $\mathrm{NO}$ synthase. We found significant increase in concentrations of asymmetric dimethylarginine $(0.84 \pm 0.32 \mu \mathrm{mol} / \mathrm{L}, \mathrm{p}=0.0022)$ and malondialdehyde $(0.77 \pm 0.11 \mu \mathrm{mol} / \mathrm{L}, \mathrm{p}<0.001)$ in sera of MDS patients vs controls (asymmetric dimethylarginine: $0.56 \pm 0.16 \mu \mathrm{mol} / \mathrm{L}$, malondialdehyde: $0.52 \pm 0.07 \mu \mathrm{mol} / \mathrm{L}$ ). On the contrary, nitrites concentrations were significantly decreased in MDS patients $(1.71 \pm 0.46 \mu \mathrm{mol} / \mathrm{L}, \mathrm{p}=0.0028)$ vs controls $(2.16 \pm 0.38 \mu \mathrm{mol} / \mathrm{L})$. We suppose that the oxidative stress in MDS is enhanced due to methylated arginines influence on $\mathrm{NO}$ synthase activity impairment.
\end{abstract}

\section{To the editor}

Myelodysplastic syndromes (MDS) are a heterogeneous group of clonal hematological disorders, characterized by ineffective hematopoiesis and a high risk of transformation into acute myeloid leukemia. It has been determined that oxidative stress plays a role in the initialization and disease progression [1]. The reactive oxygen species may oxidize tetrahydrobiopterin resulting into nitric oxide synthase (NOS) uncoupling and preferential formation to superoxide anion radical. It was found that methylarginines (asymmetric dimethylarginine - ADMA, $\mathrm{N}^{\mathrm{G}}$-monomethyl-L-arginine - MMA and symmetric dimethylarginine - SDMA), naturally occurring inhibitors of NOS [2], can profoundly increase superoxide generation from uncoupled NOS [3]. Free methylated arginines, capable of inhibiting NOS [4], are formed exclusively by the sequence of methylation of arginine residues of proteins, followed by proteolysis of these proteins. Protein arginine methylation is in mammalian cells carried out by protein arginine methyltransferases (PRMTs); many of them show links to cancer [5].

The subjects of the study are characterized in Table 1. Ethics approval (Ethics Committee of the Institute of Hematology and Blood Transfusion) and informed consent from all subjects were obtained. Serum concentration of oxidative stress marker malondialdehyde (MDA) was estimated using liquid chromatography (Shimadzu, Tokyo, Japan) of its thiobarbituric acid derivative [6]. Methylated arginines were analyzed using HILIC chromatography with MS/MS detection (ABSciex, Framingham, USA) [7]. Nitrites were assayed by chromatography using the fluorescent reaction product with 2,3-diaminonaphthalene [8].

The concentrations of methylated arginine derivatives, malondialdehyde and nitrites are summarized in the Table 2. We found significantly increased serum concentrations of ADMA, SDMA, MMA, and MDA in sera of MDS patients as compared with healthy donors. The nitrites concentrations were significantly decreased in sera

\footnotetext{
* Correspondence: Jiri.Suttnar@uhkt.cz

Institute of Hematology and Blood Transfusion, U Nemocnice 1, 128 20,

Prague, Czech Republic
}

\section{() BioMed Central}

(c) 2013 Štikarová et al.; licensee BioMed Central Ltd. This is an Open Access article distributed under the terms of the Creative Commons Attribution License (http://creativecommons.org/licenses/by/2.0), which permits unrestricted use, distribution, and reproduction in any medium, provided the original work is properly cited. 
Table 1 Baseline characteristics of MDS patients and healthy controls

\begin{tabular}{|c|c|c|}
\hline & MDS & Controls \\
\hline${ }^{a}$ Age (years) & $43.7(33-59)$ & $44.3(37-67)$ \\
\hline Male/Female & $11 / 9$ & $8 / 8$ \\
\hline aserum iron $[\mu \mathrm{mol} / \mathrm{L}]$ & $22.3(11.4-43.3)$ & b $8.5-28$ \\
\hline aserum ferritin $[\mu \mathrm{g} / \mathrm{L}]$ & $641.2(8.9-1907.3)$ & $b_{15}-150$ \\
\hline
\end{tabular}

${ }^{\mathrm{a}}$ The data are depicted as averages with ranges. ${ }^{\mathrm{b}}$ Reference interval.

Table 2 Concentrations of methylated arginines in sera of MDS patients and healthy controls

\begin{tabular}{lccc}
\hline & MDS & Controls & ${ }^{{ }^{a}} \mathbf{p}$ \\
\hline ADMA $[\mu \mathrm{mol} / \mathrm{L}]$ & $0.84 \pm 0.32$ & $0.56 \pm 0.16$ & $0.0022^{* *}$ \\
SDMA $[\mu \mathrm{mol} / \mathrm{L}]$ & $0.54 \pm 0.18$ & $0.42 \pm 0.14$ & $0.0361^{*}$ \\
MMA $[\mu \mathrm{mol} / \mathrm{L}]$ & $0.14 \pm 0.05$ & $0.10 \pm 0.03$ & $0.033^{*}$ \\
Homoarginine $[\mu \mathrm{mol} / \mathrm{L}]$ & $1.77 \pm 1.06$ & $2.32 \pm 1.26$ & 0.1777 \\
Citrulline $[\mu \mathrm{mol} / \mathrm{L}]$ & $46.68 \pm 14.96$ & $42.19 \pm 12.31$ & 0.3298 \\
MDA $[\mu \mathrm{mol} / \mathrm{L}]$ & $0.77 \pm 0.11$ & $0.52 \pm 0.07$ & $<0.001^{* * *}$ \\
Nitrites $[\mu \mathrm{mol} / \mathrm{L}]$ & $1.71 \pm 0.46$ & $2.16 \pm 0.38$ & $0.0028^{* *}$
\end{tabular}

The data are represented as averages $\pm S D$. ADMA, $N^{G}, N^{G}$-dimethyl-L-arginine; MMA, $\mathrm{N}^{\mathrm{G}}$-monomethyl-L-arginine; SDMA, $\mathrm{N}^{\mathrm{G}}, \mathrm{N}^{\mathrm{G}^{\prime}}$-dimethyl-L-arginine; MDA,

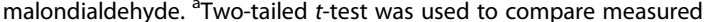
concentrations of analytes in MDS patients with healthy donors. Statistical significance coding: ${ }^{*} p<0.05,{ }^{* *} p<0.01$ and ${ }^{* *} p<0.001$.

of MDS patients as compared with controls. The concentration of ADMA strongly positively correlated with concentration of MMA $(r=0.87, \mathrm{p}<0.001)$ and SDMA $(\mathrm{r}=0.70, \mathrm{p}<0.001)$. ADMA concentration moderately positively correlated with MDA concentration $(r=0.50$, $\mathrm{p}=0.006)$.

Our results showed significantly increased oxidative stress even in MDS patients characterized by moderately enhanced iron and serum transferrin concentrations. Resulting shift of overexpressed [9] NO synthase activity in favour of superoxide production at the expense of nitric oxide synthesis (reflected by nitrites concentrations [10]) was further augmented at the presence of methylated arginines. Therefore, oxidative stress in MDS patients could be explained by a positive feedback of both superoxide and methylated arginines on original NOS activity impairment. Moreover, recently proposed PRMT-specific inhibitors [11] might have a therapeutic effect on leukemia also by oxidative stress reduction.

\section{Abbreviations}

MDS: Myelodysplastic syndromes; NOS: Nitric oxide synthase; ADMA: $N^{G}$ $N^{G}$-dimethyl-L-arginine; MMA: $N^{G}$-monomethyl-L-arginine; SDMA: $N^{G}$, $\mathrm{N}^{\mathrm{G}^{\prime}}$-dimethyl-L-arginine; MDA: Malondialdehyde; PRMT: protein arginine methyltransferase.

\section{Competing interest}

The authors indicated no potential conflicts of interest.

\section{Authors' contributions}

JŠ performed LC-MS/MS analysis of methylated derivatives of arginine. JS participated on LC-MS/MS analysis of methylated derivatives of arginine, carried out data analysis and interpretation and wrote the manuscript. KP and LCM performed malondialdehyde and nitrite analysis. JČ provided clinical data and patient samples. JED conceived of the study and wrote the manuscript. Final approval of the manuscript: All the co-authors. All authors read and approved the final manuscript.

\section{Acknowledgement}

This work was supported by Grant CZ.2.16/3.1.00/24001 of the EU ERDF OPPK, by P205/12/G118 of Centrum Excellence, by Grant KAN20067070 from the Academy of Sciences, Czech Republic and by the Ministry of Health, Czech Republic project for the conceptual development of research organization, VZ MZ 00002373601 IHBT.

Received: 17 July 2013 Accepted: 17 August 2013

Published: 19 August 2013

\section{References}

1. Farquhar MJ, Bowen DT: Oxidative stress and the myelodysplastic syndromes. Int J Hematol 2003, 77:342-350.

2. Leiper J, Vallance P: Biological significance of endogenous methylarginines that inhibit nitric oxide synthases. Cardiovasc Res 1999, 43:542-548.

3. Druhan LJ, Forbes SP, Pope AJ, Chen CA, Zweier JL, Cardounel AJ: Regulation of eNOS-derived superoxide by endogenous methylarginines. Biochemistry 2008, 47:7256-7263.

4. Teerlink T: ADMA metabolism and clearance. Vasc Med 2005, 10:S73-S81.

5. Yang Y, Bedford MT: Protein arginine methyltransferases and cancer. Nat Rev Cancer 2013, 13:37-50

6. Suttnar J, Masova L, Dyr JE: Influence of citrate and EDTA anticoagulants on plasma malondialdehyde concentrations estimated by highperformance liquid chromatography. J Chromatogr B Biomed Sci Appl 2001, 751:193-197.

7. Martens-Lobenhoffer J, Bode-Boger SM: Fast and Efficient Determination of Arginine, Symmetric Dimethylarginine, and Asymmetric Dimethylarginine in Biological Fluids by Hydrophilic-Interaction Liquid Chromatography- Electrospray Tandem Mass Spectrometry. Clin Chem 2006, 52:3488-3493.

8. Li H, Meininger $\mathrm{CJ}$, Wu G: Rapid determination of nitrite by reversedphase high-performance liquid chromatography with fluorescence detection. J Chromatogr B Biomed Sci Appl 2000, 746:199-207.

9. Kitagawa M, Takahashi M, Yamaguchi S, Inoue M, Ogawa S, Hirokawa K, Kamiyama R: Expression of inducible nitric oxide synthase (NOS) in bone marrow cells of myelodysplastic syndromes. Leukemia 1999, 13:699-703.

10. Lauer T, Preik M, Rassaf T, Strauer BE, Deussen A, Feelisch M, Kelm M: Plasma nitrite rather than nitrate reflects regional endothelial nitric oxide synthase activity but lacks intrinsic vasodilator action. Proc Natl Acad Sci U S A 2001, 98:12814-12819.

11. Copeland RA, Solomon ME, Richon VM: Protein methyltransferases as a target class for drug discovery. Nat Rev Drug Discov 2009, 8:724-732.

doi:10.1186/1756-8722-6-58

Cite this article as: Štikarová et al.: Enhanced levels of asymmetric dimethylarginine in a serum of middle age patients with myelodysplastic syndrome. Journal of Hematology \& Oncology 2013 6:58. 